\title{
Effect of retinoic acid on aquaporin 3 expression in keratinocytes
}

\author{
F. Xing, W. Liao, P. Jiang, W. Xu and X. Jin \\ Department of Dermatology, Center Hospital of Xiangyang City, Hubei Province, \\ China
}

Corresponding author: $\mathrm{X}$. Jin

E-mail: mignzhizuoxi@163.com

Genet. Mol. Res. 15 (1): gmr.15016951

Received August 11, 2015

Accepted October 29, 2015

Published March 11, 2016

DOI http://dx.doi.org/10.4238/gmr.15016951

ABSTRACT. To explore the possible mechanism of the third-generation retinoic acid drugs (isotretinoin, acitretin, adapalene) in inducing skin and mucosa dryness and rhagades; specifically, mechanism by which these drugs influence keratinocyte cell culture models in vitro (HaCaT) and aquaporin channel (AQP3) protein expression was investigated. Isotretinoin, acitretin, and adapalene were applied to human keratinocyte HaCaT cells. Immunohistochemistry, reverse transcriptase polymerase chain reaction, and western blotting were used to detect their effects on AQP3 expression in $\mathrm{HaCaT}$ cells at different concentrations $(0.000,0.001,0.010,0.060$, and $0.100 \mathrm{mg} / \mathrm{mL})$ or different at times $(0,6,12,24$, and $48 \mathrm{~h})$. At $0.010 \mathrm{mg} /$ $\mathrm{mL}$, maximal AQP3 expression was observed in $\mathrm{HaCaT}$ cells; this was significantly higher than the expressions at the other concentrations $(P<$ 0.05). After treatment with isotretinoin, acitretin, or adapalene at $0.010 \mathrm{mg} /$ $\mathrm{mL}$ for $12 \mathrm{~h}$, the expression of AQP3 was the highest in the isotretinoin group, followed by the acitretin group, with the lowest expression in the adapalene group. However, the differences were not statistically significant $(P>0.05)$. Retinoic acid can increase AQP3 expression in HaCaT cells, with significant effects observed with $0.010 \mathrm{mg} / \mathrm{mL}$ isotretinoin treatment 
for $12 \mathrm{~h}$. The side effects, namely skin and mucosa dryness caused by retinoic acid might be related to its effects on AQP3 expression.

Key words: Aquaporin 3; Retinoic acid; Keratinocyte; Epithelial cell

\section{INTRODUCTION}

Retinoic acid is a vitamin A derivative. It has been widely used in a variety of diseases such as abnormal keratinization and hyperplastic dermatosis, and in beauty treatments for antiaging and anti-oxidation, after being regarded as the third milestone in the history of skin disease treatment with clear curative effect in 1971 (Agren et al., 2003; Hara-Chikuma and Verkman, 2005). However, one of retinoic acid most obvious and inevitable side effects is skin and mucosa dryness, desquamation, and rhagades. General treatment such as water replenishment or moisturization cannot ameliorate the symptoms. Numerous patients discontinue treatment because of intolerance and then lose the opportunity to cure their disease (Elias and Schmuth, 2009). Aquaporins (AQPs) are proteins located on the cell membrane. They create channels on the cell membrane, which can control the flow of water through the cell membrane like a "cell pump". Eleven types of AQPs have been discovered in the human body thus far. They exist not only in the ependyma, heart, alveoli, biliary system, kidney, lens internal capsule, exocrine gland epithelial cells, and some organs involved with metal and water metabolism, but also in the keratinocyte membrane of the epidermis (Choi et al., 2005; Olsson et al., 2006; Qi et al., 2009). Several references have already confirmed that AQP3 plays an important role in the recovery of skin barrier functions (Sugiyama et al., 2001; Roudier et al., 2002; Boury-Jamot et al., 2006). The improvement in skin moisture and dry skin diseases can be achieved through regulation of AQP3 expression and function. References regarding the association between AQP3 expression and skin dryness side effects caused by retinoic acid are still lacking; however, there are references to explain the mechanism of skin and mucosa dryness and rhagades caused by retinoic acid (Salo et al., 2011). Therefore, we speculate that the skin and mucous dryness caused by retinoic acid is related to its effects on AQP3 expression.

As a cell line transformed from adult human epidermal cells, the HaCaT cell line has inherent immortality and proliferative and differentiable properties similar to those of keratinocytes. It also has stable inheritance without tumor formation. Therefore, to prove our hypothesis, we treated human keratinocyte HaCaT cells with retinoic acid-related drugs isotretinoin, acitretin, and adapalene to study the effect of retinoic acid on AQP3 expression. We aimed to provide a theoretical basis for clinical treatment to screen drugs that can alter AQP3 expression and to explore the approaches to reduce or eliminate side effects.

\section{MATERIAL AND METHODS}

\section{Main reagents, cells, and instruments}

\section{Reagents}

Human-derived keratinocyte HaCaT cells (from Chinese Academy of Sciences cell bank), serum-containing complete medium and serum-free medium (Gibco, USA), PCR kit (Solomon Biotech Co., Ltd, Shanghai, China), immunohistochemical kit (Boster, Wuhan, China), horseradish peroxidase (HRP)-tagged goat anti-mouse IgG and HRP-tagged goat anti-rabbit lgG (Beyo- 
time Biotechnology, Shanghai, China), EDTA-containing trypsin (Gibco), primary antibody: AQP3 mouse monoclonal IgG and $\beta$-actin rabbit Polyclonal IgG (Santa Cruz, CA, USA). Isotretinoin (brand name: Taiersi, produced by Shanghai Symyanan Pharmaceutical Co., Ltd., Shanghai, China), acitretin (brand name: Fangxi, Chongqing Huapont pharmaceutical Co., Ltd., Chongqing, China), and adapalene (brand name: Differin, produced by Galderma, France). The three drugs above contain active ingredient in 40,20 , and $400 \mathrm{mg}$, respectively, in a 10-mL sample.

\section{Instruments}

Super clean bench (Suzhou Purification Equipment Co., Ltd., Jiangsu, China), incubator (Queue Systems, USA), inverted phase contrast microscope (Olympus, Japan), centrifuge (BiofugeStratos, German), refrigerator with $-80^{\circ}$ to $-40^{\circ} \mathrm{C}$ adjustable temperature (Panasonic, Japan), disinfect box (Tuttnauer, USA), electrophoresis system (Bio-Rad, USA), PCR amplifier (Rotor-gene, Australia).

\section{Cell culture and passage}

HaCaT cells were passage-cultured in DMEM (Wu et al., 2011) containing 10\% fetal bovine serum and penicillin-streptomycin in an incubator at $37^{\circ} \mathrm{C}$ and $5 \% \mathrm{CO}_{2}$. When the cell density reached more than $4 \times 10^{6}$, they were digested by $0.02 \%$ EDTA-containing trypsin. Digestion was stopped when the cells retracted under inverted microscope. Then, an equal volume of medium containing serum and buffered was added to the cells. After centrifugation at 10,000 rpm for $5 \mathrm{~min}$, the supernatant was discarded and the cell suspensions were counted and moved to new flasks.

\section{Grouping and treatment}

The cells were treated with isotretinoin, acitretin, or adapalene at different concentrations $(0.000,0.001,0.010,0.060$, and $0.100 \mathrm{mg} / \mathrm{mL})$ or different time duration $(0,6,12$, 24, and $48 \mathrm{~h})$ when cell density reached more than $4 \times 10^{6}$.

\section{Immunochemistry}

Human-derived keratinocyte HaCaT cells were tested by SP assay to detect immunohistochemistry results. Cells in all groups were collected, rinsed three times in $0.01 \mathrm{M}$ PBS and fixed in 4\% paraformaldehyde for $15 \mathrm{~min}$. Endogenous hydrogen peroxidase activity was blocked with $3 \%$ hydrogen peroxide and $50 \mu \mathrm{L}$ non-immune animal serum. Then, $50 \mu \mathrm{L}$ AQP3 primary antibody was added and the cells were incubated overnight with $50 \mu \mathrm{L}$ biotin-tagged secondary antibody and horseradish peroxidase. DBA was applied for coloration, hematoxylin was used for re-dyeing, and neutral gum was utilized to enclose.

\section{RT-PCR (semi-quantitative reverse transcriptase polymerase chain reaction) method}

From $100 \mathrm{mg} \mathrm{HaCaT}$ cells, we extracted the total RNA. The cDNA was synthesized with $2 \mu \mathrm{g}$ RNA from the samples. We used $20 \mu \mathrm{g}$ cDNA as the reaction system. The PCR reaction consisted of an initial single cycle of $5 \mathrm{~min}$ at $95^{\circ} \mathrm{C}$ followed by 30 cycles of $30 \mathrm{~s}$ at $94^{\circ} \mathrm{C}, 30 \mathrm{~s}$ at $60^{\circ} \mathrm{C}$, 
and $60 \mathrm{~s}$ at $72^{\circ} \mathrm{C}$, respectively. PCR products were analyzed by agarose gel electrophoresis and the electrophoresis images were photographed for analysis. AQP3 expression levels were quantified relative to the expression of 18s RNA, the PCR system images were finished as mentioned above, and the semi-quantitative results were analyzed comparatively, through the absorbance point values (A value).

\section{Western blotting}

$\mathrm{HaCaT}$ cells were harvested and homogenized with lysis buffer. Total protein was separated by denaturing $10 \%$ SDS-polyacrylamide gel electrophoresis, using semi-dry transfer film. The membrane was incubated with AQP3 primary antibody (1:500) at $4^{\circ} \mathrm{C}$ overnight, followed by secondary antibody incubation $(1: 1000)$ at $37^{\circ} \mathrm{C}$ for $1 \mathrm{~h}$. Detection and analysis were performed by the ECL photochemical method and color image analysis system was used for measuring absorbance.

\section{Statistical analysis}

All statistical analyses were conducted with SPSS21.0 software (Chicago, IL, USA). Data with normal distribution are presented as means and standard deviation, and with abnormal distribution were presented using the median and interquartile range. LSD test was applied using two-group comparison, with normal distribution and homogeneity of variance. A nonparametric test was used for AQP3 mRNA and protein comparison after the cells were treated by isotretinoin, acitretin, or adapalene under different concentrations or different time, respectively. The KruskalWallis $\mathrm{H}$ test was performed for null-groups comparison. The Mann-Whitney $\mathrm{U}$ test was used for dual-groups comparison. $\mathrm{P}<0.05$ was considered to indicate a statistically significant result.

\section{RESULTS}

\section{Result evaluation}

The positive cells appeared with a deep tan color in cytoplasm and cell membrane under the inverted microscope. The average optical density was measured by the Image J software.

\section{AQP3 expression detected by immunochemistry}

AQP3 was minimally expressed and stained weakly in untreated $\mathrm{HaCaT}$ cells. After stimulation by isotretinoin, acitretin, or adapalene, AQP3 expression was significantly up-regulated (Figure 1). Statistical analysis of average optical density showed that the three drug-treated groups had significantly higher values than those in the control group (Figure 2, $\mathrm{P}<0.05$ ). Further comparison among those three groups, however, did not reveal any significant difference $(P>0.05)$.

\section{AQP3 mRNA expression in HaCaT cells after treatment by different concentra- tions of isotretinoin, acitretin, or adapalene for $24 \mathrm{~h}$}

After treatment of HaCaT cells with different concentrations of isotretinoin, acitretin, or adapalene, AQP3 mRNA expression at $0.010 \mathrm{mg} / \mathrm{mL}$ stimulation was significantly higher than that observed after stimulation with other concentrations $(P<0.05)($ Table 1$)$. 

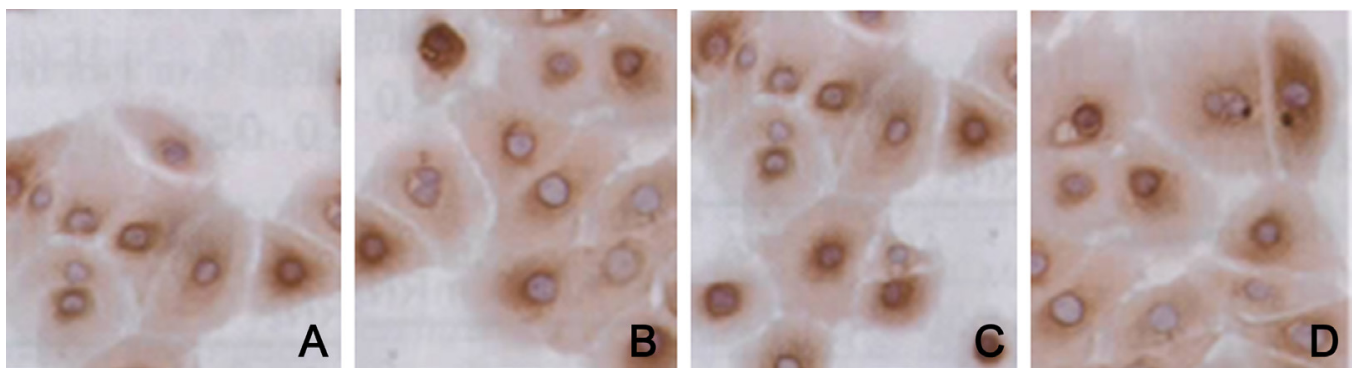

Figure 1. Immunohistochemical (IHC) staining of AQP3 in HaCaT cells. A.-D. Representative images from control, isotretinoin, acitretin, and adapalene group, respectively. Magnification 200X.

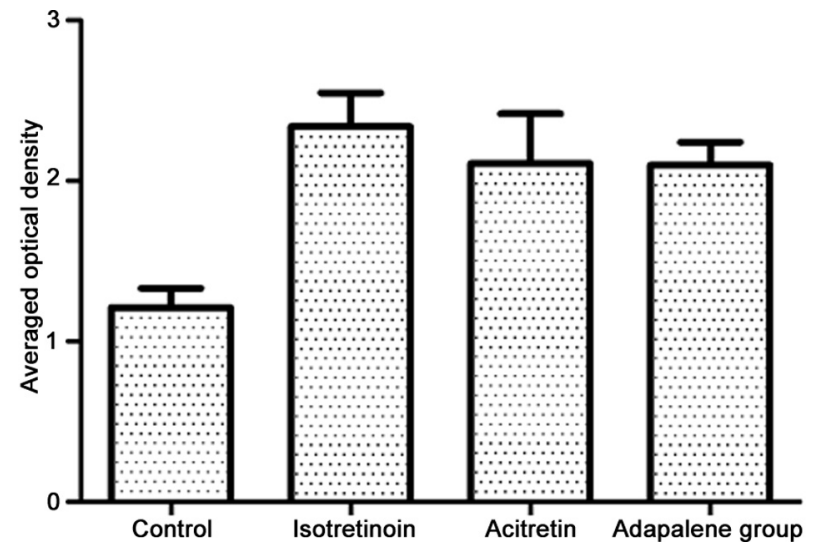

Figure 2. Averaged optical density of AQP3 staining. The Image $\mathrm{J}$ software analyzed the averaged optical density across all groups of $\mathrm{HaCaT}$ cells and plotted their relative expression levels of AQP3.

Table 1. AQP3 mRNA expression in HaCaT cells after treatment with different concentrations of isotretinoin, acitretin, or adapalene.

\begin{tabular}{l|c|c|c}
\hline \multirow{2}{*}{ Concentration $(\mathrm{mg} / \mathrm{mL})$} & \multicolumn{3}{|c}{ AQP3 mRNA } \\
\cline { 2 - 4 } & Isotretinoin & Acitretin & Adapalene \\
\hline 0.000 & $0.82 \pm 0.31^{1}$ & $0.72 \pm 0.26^{1}$ & $0.72 \pm 0.29^{1}$ \\
\hline 0.001 & $1.12 \pm 0.56^{1}$ & $1.10 \pm 0.29^{1}$ & $1.03 \pm 0.33^{1}$ \\
\hline 0.010 & $1.70 \pm 0.56$ & $1.56 \pm 0.45$ & $1.45 \pm 0.44$ \\
\hline 0.060 & $1.16 \pm 0.69^{1}$ & $1.22 \pm 0.36^{1}$ & $1.05 \pm 0.42^{1}$ \\
\hline 0.100 & $0.68 \pm 0.23^{1}$ & $0.87 \pm 0.31^{1}$ & $0.98 \pm 0.26^{1}$ \\
\hline
\end{tabular}

${ }^{1} \mathrm{P}<0.05$ compared with concentration at $0.010 \mathrm{mg} / \mathrm{mL}$.

AQP3 mRNA expression in HaCaT cells after treatment with isotretinoin, acitretin, or adapalene at $0.010 \mathrm{mg} / \mathrm{mL}$ at different time periods

After treatment of $\mathrm{HaCaT}$ cells with isotretinoin, acitretin, or adapalene at $0.010 \mathrm{mg} / \mathrm{mL}$, AQP3 mRNA expression began to increase at $6 \mathrm{~h}$ and reached a peak at $12 \mathrm{~h}$. Within the first 12 $\mathrm{h}, \mathrm{AQP} 3 \mathrm{mRNA}$ expression was the highest in the isotretinoin group, followed by expression in the acitretin group. AQP3 mRNA showed the lowest expression in the adapalene group. ( $P<0.05$ for all comparisons) (Table 2). 
Table 2. AQP3 mRNA expression in HaCaT cells after treatment with isotretinoin, acitretin, or adapalene at different times.

\begin{tabular}{l|c|c|c}
\hline \multirow{2}{*}{ Time (h) } & \multicolumn{3}{|c}{ AQP3 mRNA } \\
\cline { 2 - 4 } & Isotretinoin & Acitretin & Adapalene \\
\hline 0 & $0.79 \pm 0.28^{1}$ & $0.70 \pm 0.24^{1}$ & $0.66 \pm 0.25^{1}$ \\
\hline 6 & $1.10 \pm 0.54^{1}$ & $1.08 \pm 0.27^{1}$ & $1.01 \pm 0.31^{1}$ \\
\hline 12 & $1.45 \pm 0.56$ & $1.31 \pm 0.43$ & $1.31 \pm 0.42$ \\
\hline 24 & $1.14 \pm 0.47^{1}$ & $1.20 \pm 0.31^{1}$ & $0.03 \pm 0.39^{1}$ \\
\hline 48 & $0.66 \pm 0.22^{1}$ & $0.85 \pm 0.29^{1}$ & $0.96 \pm 0.24^{1}$ \\
\hline
\end{tabular}

${ }^{1} \mathrm{P}<0.05$ compared with $12 \mathrm{~h}$.

\section{AQP3 protein expression in $\mathrm{HaCaT}$ cells after treatment with different concentra- tions of isotretinoin, acitretin, or adapalene for $24 \mathrm{~h}$}

After treatment of $\mathrm{HaCaT}$ cells for $24 \mathrm{~h}$ with different concentrations of isotretinoin, acitretin, or adapalene, the expression patterns of AQP3 protein were found to be consistent with those of mRNA. The expression of AQP3 was the highest after $0.010 \mathrm{mg} / \mathrm{mL}$ stimulation than that after stimulation with the other concentrations $(P<0.05)$ (Table 3$)$.

\begin{tabular}{|c|c|c|c|}
\hline \multirow[t]{2}{*}{ Concentration $(\mathrm{mg} / \mathrm{mL})$} & \multicolumn{3}{|c|}{ AQP3 protein } \\
\hline & Isotretinoin & Acitretin & Adapalene \\
\hline 0.000 & $1.39 \pm 0.56^{1}$ & $1.72 \pm 0.86^{1}$ & $1.76 \pm 0.86^{1}$ \\
\hline 0.001 & $1.52 \pm 0.72^{1}$ & $1.98 \pm 0.76^{1}$ & $1.99 \pm 1.23^{1}$ \\
\hline 0.010 & $3.23 \pm 1.99$ & $2.56 \pm 1.86$ & $2.45 \pm 1.22$ \\
\hline 0.060 & $1.96 \pm 0.86^{1}$ & $1.99 \pm 0.86^{1}$ & $1.76 \pm 0.96^{1}$ \\
\hline 0.100 & $1.23 \pm 0.73^{1}$ & $1.59 \pm 0.85^{1}$ & $1.69 \pm 0.95^{1}$ \\
\hline
\end{tabular}

${ }_{1}^{1} \mathrm{P}<0.05$ compared with concentration at $0.010 \mathrm{mg} / \mathrm{mL}$.

\section{AQP3 protein expression in HaCaT cells after treatment with isotretinoin, acitre- tin, or adapalene at $0.010 \mathrm{mg} / \mathrm{mL}$ at different times}

After treatment of HaCaT cells with isotretinoin, acitretin, or adapalene at $0.010 \mathrm{mg} / \mathrm{mL}$, AQP3 expression began to increase at $6 \mathrm{~h}$ and reached a maximum at $12 \mathrm{~h}$. It expressed highest in the isotretinoin group, followed by expression in the acitretin group, and was lowest in the adapalene group. $(\mathrm{P}<0.05)$ (Table 4$)$.

Table 4. AQP3 protein expression in HaCaT cells after treatment with isotretinoin, acitretin, or adapalene at different times.

\begin{tabular}{l|c|c|c}
\hline \multirow{2}{*}{ Time $(\mathrm{h})$} & \multicolumn{3}{|c}{ AQP3 protein } \\
\cline { 2 - 4 } & Isotretinoin & Acitretin & Adapalene \\
\hline 0 & $1.92 \pm 0.86^{1}$ & $1.70 \pm 0.98^{1}$ & $1.65 \pm 0.87^{1}$ \\
\hline 6 & $2.03 \pm 1.06^{1}$ & $1.88 \pm 0.27^{1}$ & $2.04 \pm 0.85^{1}$ \\
\hline 12 & $2.65 \pm 1.23$ & $2.21 \pm 0.98$ & $1.86 \pm 0.89^{1}$ \\
\hline 24 & $1.96 \pm 1.02^{1}$ & $1.86 \pm 0.85^{1}$ & $1.65 \pm 0.73^{1}$ \\
\hline 48 & $1.66 \pm 0.96^{1}$ & $1.84 \pm 0.81^{1}$ & \\
\hline
\end{tabular}

${ }^{1} \mathrm{P}<0.05$ compared with $12 \mathrm{~h}$. 


\section{DISCUSSION}

Widely used in dermatology, retinoic acid is a drug that can promote the normal keratinization process by inhibiting abnormal keratinocyte proliferation and differentiation (Pokharel et al., 2008). It also has an anti-inflammatory role by mediating the release function of lysosome and the chemotaxis of neutrophils to inhibit sebaceous differentiation. In clinical settings, topical application of retinoic acid drugs can be used to treat acne and keratinized skin with a definite curative effect (Kozono et al., 2002; Park et al., 2008). However, one of its inevitable side effects is skin and mucosa dryness. General water replenishment cannot relieve the symptoms. Many patients discontinue treatment because of intolerance, before a cure is achieved (Verdier-Sévrain and Bonté, 2007).

Aquaporin is a type of water-specific membrane protein that is constantly acknowledged by scientists. Since its discovery in 1988, researchers have found a variety of aquaporins. The permeability of AQP3 to glycerol was reported in 1994 that can lead to further understanding of aquaporins (Sougrat et al., 2002; Song et al., 2008). The high permeability of AQP3 allows it to carry not only water, but also endogenous glycerin and triglycerides from the sebaceous glands to the epidermis, resulting in its involvement in epidermal cell glycerol metabolism (Magann et al., 2007).

Major cell lines in in vitro studies of epidermis include COLO-16 and HaCaT cell lines. The former is derived from epidermal squamous cancer cells and is malfunction. The latter cell line, $\mathrm{HaCaT}$, is transformed from immortal keratinocytes of human epidermis and has a stable proliferation pattern and minimal mutations even with intensive passages. The most prominent feature of the HaCaT cell line is its function, similar to that of normal keratinocytes. Our results showed that untreated HaCaT cells only weakly expressed AQP3. The addition of isotretinoin, acitretin, or adapalene can stimulate the expression of AQP3 in cells. Statistical analysis of average optical density showed that the three drug-treated groups had significantly higher expression values than did the control group (Figure 2; $\mathrm{P}<0.05$ ). Further comparison among those three groups, however, did not reveal any significant difference $(P>0.05)$. When HaCaT cells were treated with different concentrations of isotretinoin, acitretin, or adapalene, AQP3 expression at $0.010 \mathrm{mg} / \mathrm{mL}$ was significantly higher than that at the other concentrations. After treatment with isotretinoin, acitretin, or adapalene at $0.010 \mathrm{mg} / \mathrm{mL}$ for different time durations, AQP3 mRNA and protein expressions began to increase at $6 \mathrm{~h}$ and reached their peak at $12 \mathrm{~h}$. Their expression was the highest in the isotretinoin group and the mid-range in the adapalene group.

It was found that retinoic acid stimulation could upregulate the number of AQP3-positive cells and mRNA and protein expression, similar to its effects on skin moisture content. Increased AQP3 expression damages the skin barrier, leaves the cell in a high-permeability state, and causes side effects such as skin dryness. Additionally, we observed that following the increase in concentration, AQP3 expression reached a peak and was subsequently down-regulated, which might be associated with high drug concentration and long treatment period, both of which may cause the drug to not be fully metabolized, leading to alterations in osmotic pressure. Elevated osmotic pressure may damage cell structure, even causing membrane dissolution and cell death (Takata et al., 2004). Considering the pharmacological effects of retinoic acid and our results, this drug not only has anti-inflammatory effect, but also can promote AQP3 expression in the epidermis of the HaCaT cells to function as skin mucous membrane barrier repairmen (Hara and Verkman, 2003). Thus, proper dosage and duration may reduce the side effects and maintain the best treatment effect of retinoic acid. Consistent regulation of treatment is essential. For this in vitro study, we did not consider how regulating the internal environment of the cell would affect the drug function. The appropriate drug concentration still needs further verification. 
In summary, by investigating the effect of retinoic acid drugs on AQP3 expression in keratinocyte $\mathrm{HaCaT}$ cells, we suggested that AQP3 expression is closely related to drug intervention. It is necessary to further explore AQP3 effect in vivo, to clarify the drug mechanism further and to provide a theoretical basis for clinical treatment.

\section{Conflicts of interest}

The authors declare no conflict of interest.

\section{ACKNOWLEDGMENTS}

We thank the anonymous reviewers for reviewing this manuscript.

\section{REFERENCES}

Agren J, Zelenin S, Håkansson M, Eklöf AC, et al. (2003). Transepidermal water loss in developing rats: role of aquaporins in the immature skin. Pediatr. Res. 53: 558-565. http://dx.doi.org/10.1203/01.PDR.0000055777.25933.98

Boury-Jamot M, Sougrat R, Tailhardat M, Le Varlet B, et al. (2006). Expression and function of aquaporins in human skin: Is aquaporin-3 just a glycerol transporter? Biochim. Biophys. Acta 1758: 1034-1042. http://dx.doi.org/10.1016/j. bbamem.2006.06.013

Choi EH, Man MQ, Wang F, Zhang X, et al. (2005). Is endogenous glycerol a determinant of stratum corneum hydration in humans? J. Invest. Dermatol. 125: 288-293.

Elias PM and Schmuth M (2009). Abnormal skin barrier in the etiopathogenesis of atopic dermatitis. Curr. Opin. Allergy Clin. Immunol. 9: 437-446. http://dx.doi.org/10.1097/ACl.0b013e32832e7d36

Hara M and Verkman AS (2003). Glycerol replacement corrects defective skin hydration, elasticity, and barrier function in aquaporin-3-deficient mice. Proc. Natl. Acad. Sci. USA 100: 7360-7365. http://dx.doi.org/10.1073/pnas.1230416100

Hara-Chikuma M and Verkman AS (2005). Aquaporin-3 functions as a glycerol transporter in mammalian skin. Biol. Cell 97 479-486. http://dx.doi.org/10.1042/BC20040104

Kozono D, Yasui M, King LS and Agre P (2002). Aquaporin water channels: atomic structure molecular dynamics meet clinical medicine. J. Clin. Invest. 109: 1395-1399. http://dx.doi.org/10.1172/JCl0215851

Magann EF, Chauhan SP, Doherty DA, Lutgendorf MA, et al. (2007). A review of idiopathic hydramnios and pregnancy outcomes. Obstet. Gynecol. Surv. 62: 795-802. http://dx.doi.org/10.1097/01.ogx.0000290349.58707.e0

Olsson M, Broberg A, Jernås M, Carlsson L, et al. (2006). Increased expression of aquaporin 3 in atopic eczema. Allergy 61: 1132-1137. http://dx.doi.org/10.1111/j.1398-9995.2006.01151.x

Park CW, Youn M, Jung YM, Kim H, et al. (2008). New functional probiotic Lactobacillus sakei probio 65 alleviates atopic symptoms in the mouse. J. Med. Food 11: 405-412. http://dx.doi.org/10.1089/jmf.2007.0144

Pokharel YR, Lim SC, Kim SC, Heo TH, et al. (2008). Sopungyangjae-tang inhibits development of dermatitis in nc/nga mice. Evid. Based Complement. Alternat. Med. 5: 173-180. http://dx.doi.org/10.1093/ecam/nem015

Qi XF, Kim DH, Yoon YS, Li JH, et al. (2009). Effects of Bambusae caulis in Liquamen on the development of atopic dermatitislike skin lesions in hairless mice. J. Ethnopharmacol. 123: 195-200. http://dx.doi.org/10.1016/j.jep.2009.03.020

Roudier N, Bailly P, Gane P, Lucien N, et al. (2002). Erythroid expression and oligomeric state of the AQP3 protein. J. Biol. Chem. 277: 7664-7669. http://dx.doi.org/10.1074/jbc.M105411200

Salo PM, Calatroni A, Gergen PJ, Hoppin JA, et al. (2011). Allergy-related outcomes in relation to serum IgE: results from the National Health and Nutrition Examination Survey 2005-2006. J. Allergy Clin. Immunol. 127: 1226-1235 e7.

Song X, Xu A, Pan W, Wallin B, et al. (2008). Nicotinamide attenuates aquaporin 3 overexpression induced by retinoic acid through inhibition of EGFR/ERK in cultured human skin keratinocytes. Int. J. Mol. Med. 22: 229-236.

Sougrat R, Morand M, Gondran C, Barré P, et al. (2002). Functional expression of AQP3 in human skin epidermis and reconstructed epidermis. J. Invest. Dermatol. 118: 678-685. http://dx.doi.org/10.1046/j.1523-1747.2002.01710.x

Sugiyama Y, Ota Y, Hara M and Inoue $S$ (2001). Osmotic stress up-regulates aquaporin-3 gene expression in cultured human keratinocytes. Biochim. Biophys. Acta 1522: 82-88. http://dx.doi.org/10.1016/S0167-4781(01)00320-7

Takata K, Matsuzaki T and Tajika Y (2004). Aquaporins: water channel proteins of the cell membrane. Prog. Histochem. Cytochem. 39: 1-83. http://dx.doi.org/10.1016/j.proghi.2004.03.001 
Verdier-Sévrain S and Bonté F (2007). Skin hydration: a review on its molecular mechanisms. J. Cosmet. Dermatol. 6: 75-82. http://dx.doi.org/10.1111/j.1473-2165.2007.00300.x

Wu KG, Li TH, Chen CJ, Cheng HI, et al. (2011). Correlations of serum Interleukin-16, total IgE, eosinophil cationic protein and total eosinophil counts with disease activity in children with atopic dermatitis. Int. J. Immunopathol. Pharmacol. 24: 15-23. 